The results of microbiological analysis of the soil selected for different grain crops indicate that the root exudates of plants create favorable conditions for the vital activity of microorganisms. Comparison of the state of populations from agricultural areas with the microbiota of the biocenosis indicates the importance of including perennial grain crops in the crop rotation, which will increase the number of microorganisms in the rhizosphere and improve the conditions for the passage of soil-forming processes.

Key words: ecological-trophic groups of microorganisms, biological activity of soil, podzolized black earth, fallow, spelled, Khors, Kernza ${ }^{\circledR}$.

UDC: 631.55/.58: 633.11/.14 + 633.35

DOI 10.31395/2415-8240-2020-97-1-16-22

\title{
BINARY SOWINGS AS A BASIS FOR THE INTENSIFICATION OF FODDER PRODUCTION INDUSTRY
}

\author{
H. I. DEMYDAS, Doctor of Agricultural Sciences \\ The National University of Life and Environmental Sciences of Ukraine \\ S. P. POLTORETSKYI, Doctor of Agricultural Sciences \\ Uman National University of Horticulture \\ L. M. BURKO, Candidate of Agricultural Sciences \\ S. S. VEILER, post-graduate student \\ The National University of Life and Environmental Sciences of Ukraine
}

Проведено аналітичний огляд украӥнського та світового передового досвіду щодо вирощування вики посівної в бінарних посівах. Проаналізовано наукові публікації вітчизняних і закордонних учених з питань значення бінарних посівів у кормовиробництві, підбору культур для сумісного вирощування. Проведено узагальнення і систематизація вивченого матеріалу. Встановлено, щзо вика посівна переважно культивується в сумішках з ярими хлібними злаками. Цю культуру можна вирощувати як за весняної, так і літньої сівби в післяукісних і післяжнивних посівах з вівсом, ячменем, суданською травою й іншими ярими культурами; за посушливих умов з континентальним кліматом на сіно та насіння. Проте, врожай насіння в таких регіонах дуже низький $i$ значно варіює залежно від кількості та розподілу весняних дощів. Забезпечення тваринництва високоякісними кормами за рахунок бобово-злакових сумімей однорічних культур дає можливість розширити асортимент кормів у раціонах жуйних тварин у стійловий період.

Ключові слова: вика посівна, бінарні посіви, урожайність, зелена маса, поживність, тритикале, кормові одиниці, сумісні посіви.

Introduction. A strong fodder base is the most important element for a successful increase in livestock production. In this case, a significant role is played by cereal-and-legume crops, as they are the main source of amino acid-balanced, the 
cheapest, environmentally friendly protein. Deficiency of latter is the main reason for overuse of fodder, low productivity in livestock production. Grains of legume crops contain 200-300 g of digestible protein per fodder unit, while green mass contains $150-200 \mathrm{~g}$. The needs of livestock production in fodders are met by $70-75 \%$ due to cereal-and-legume crops [1].

However, the expected efficiency does not achieve under the use of green mass only from single-crop sowings of legumes, but on the contrary, animal productivity is reduced and fodders are used irrationally. At the same time, feeding fodder from cereal-and-legume mixtures is changed into a positive factor of the impact on the animal's organism, because not only the overall nutritional value of the diet improves, but also its qualitative indicators increases [2].

Analysis of recent researches and publications. Common vetch or common tare (Vicia sativa L.) among the biodiversity of annual legumes deserves attention. This is a valuable highly nutritious fodder crop used for green fodder, hay, grain, silage. Common vetch or common tare is an annual plant of $30-90 \mathrm{~cm}$ in height. It forms tenacious stems covered with paripinnate leaves ending in branched tendrils. There are 6-8 pairs of leaves. The flowers are placed in pairs in the axils of the leaves, $1 \mathrm{~cm}$ long or more. The cups have five teeth. Corolla is apopetalous, has a purple flag, pink wings and a slipcover is of the same colour (sometimes whitish).

The crop is undemanding to soil fertility and is characterized by a short growing season, which allows it to be grown in occupied pairs. There are $2.4 \mathrm{~kg}$ of digestible protein in $100 \mathrm{~kg}$ of green mass of common vetch, which corresponds to 16.3 fodder units, $2.2 \mathrm{~kg}$ and 46.5 fodder units, respectively, in $100 \mathrm{~kg}$ of hay. Grain of the crop contains $26 \%$, and straw and chaff - up to $10 \%$ of protein.

Common vetch is suitable for growing in joint sowings with cereals for green fodder or for harvesting of other types of fodder due to the successful combination of morphogenetic features and biological peculiarities of growth and development [3].

It was found [4] that common vetch is mainly cultivated in mixtures with spring cereals. This crop can be grown for both spring and summer sowing in topping and post-harvest sowings with oats, barley, Sudan grass and other spring crops; for hay and seeds - in arid conditions with a continental climate. However, seed yields in such regions are very low and vary considerably depending on the amount and distribution of spring rains.

Purpose. To conduct an analytical review of Ukrainian and world best practices on common vetch growing in binary crops.

Methodology of research. General scientific methods, in particular, the following: hypothesis, observation, analysis, synthesis, induction and deduction, abstraction and generalization were used during the research. Own observations and literature sources from the chosen field of research were the material. Scientific publications of domestic and foreign scientists on the significancy of binary crops in fodder production, selection of crops for joint growing were analyzed to achieve this purpose. Generalization and systematization of the studied material was carried out.

Research Results. The correct selection of components in the process of studying the issue of mixtures formation is the most important. This will ensure the 
highest yields under the conditions of efficient use of all factors of growth and development, such as solar energy, moisture, soil, nutrient content and competition between plants in the actual agrophytocenosis [5].

Studies show that the most productive and balanced grass mixtures are those that include components of such families as cereals (Poaceae), legumes (Faboideae). The advantages of multicomponent mixtures over simple sowings are in ensuring of much higher stable productivity, balanced state of fodders by digestible protein. In addition, they are characterized by a higher composition of amino acids, vitamins, macro- and micronutrients, as well as the ability to extend the shelf life without significant changes in chemical composition [6].

When growing common vetch in mixtures with cereals, it is important that their periods of maximum accumulation of green mass and the onset of topping maturity coincide. They coincide with wheat and triticale in this crop, when at the time of their flowering legumes are in the phase of mass flowering. In rye, the earing phase occurs 10-12 days earlier than in other cereals, when peas are still in the budding phase. Therefore, its share in this mixture is lower than in a mixture with wheat and triticale.

Mixed sowings of common vetch show higher yields compared to single-crop sowings. According to Richard Hoffman [7], a mixture of crop with triticale is better resistant to drought and is characterized by higher heat resistance and provides the maximum gross harvest of green mass under sufficient moisture.

The first place among forage crops can be given to multicomponent annual grass mixtures in terms of nutritional quality due to the content of protein, fat, nitrogen-free extractives and a fairly high digestibility.

When growing legume-and-cereal mixtures for fodder, it is necessary to use high-stem varieties of cereals, while it is necessary to sow it in a mixture with shortstem and semi-dwarf varieties of cereals when growing common tare for seeds.

Experiments conducted in different regions of Australia prove the benefits of introducing legume-and-cereal mixtures in crop rotation. There is an increase in nitrogen in the soil, improvement of its structure and reduction of weeds. Savings on herbicides and fertilizers are one of the main factors in the use of mixed sowings of cereals and common tare in crop rotation. In addition, the latter is an excellent precursor for wheat when grown on hay, which yield and protein indicators increase by 25 and $1.8 \%$, respectively, compared with monosowing [8].

According to the statements by M. I. Bakhmat [9], it is advisable to apply 15$20 \mathrm{t} / \mathrm{ha}$ of manure or compost or 30-45 kg/ha of phosphorus-and-potassium fertilizers in autumn and $20-30 \mathrm{~kg} / \mathrm{ha}$ of nitric fertilizers in spring for legume-and-cereal mixtures with adding of common vetch.

Accumulation of phosphorus by plants of common vetch is most active at the beginning of the growing season. The root system develops more intensively in plants with optimal phosphorus nutrition, which provides a fairly high frost and drought resistance, while the plants lag in growth and development in the absence of this nutrient. Potassium increases the resistance of plants against fungal diseases and low temperatures, promotes the formation of a strong stem, intensifies the outflow of carbohydrates from the leaves into beans. In the case of sufficient potassium 
nutrition, the plants retain moisture more fully, by the aid of which their drought resistance increases. Nitrogen accumulation occurs intensively in the early stages of growth and development under active nitrogen fixation.

Herewith the plants not only need enough amounts of nutrients for own growth and development, but also take out them with yield at formation of vegetative mass. According to a number of scientists, winter legume-and-cereal mixtures remove from the soil about $34-45 \mathrm{~kg}$ of nitrogen, $35-45 \mathrm{~kg}$ of phosphorus and $50-60 \mathrm{~kg}$ of potassium under a green mass yield of $20 \mathrm{t} / \mathrm{ha}$ [10].

The ratio of components in the mixture significantly influences the growth and development of agrophytocenosis, where the highest indicators plant height of highprotein crop of $62 \mathrm{~cm}$ and the lowest indicators - in single-crop sowing of $56 \mathrm{~cm}$ were obtained at sowing of $25 \%$ of common vetch and $75 \%$ of cereal component.

Fodder productivity of legume-and-cereal mixtures of winter annual crops is largely determined by the ratio of components. Thus, in the conditions of the western Forest-Steppe of Ukraine, joint sowings of common vetch and cereals for green fodder are recommended to be grown at sowing rates of bean component of 40-50 and $60-80 \mathrm{~kg} / \mathrm{ha}$ of rye, or wheat of $80-100 \mathrm{~kg} / \mathrm{ha}$ [11].

Great attention should be paid to the preservation of legumes in mixtures and use crops in which the seeds differ in size and weight when creating models of phytocenoses in the connection of insufficient supply by mineral fertilizers, especially nitric, which is at the first minimum in the soil.

Studies by a number of scientists show that mixtures of legumes with cereals contribute to a fuller assimilation of fodders with high content in fiber. This is due to the fact that the nitrogen of legumes is partially absorbed by unicellular fungi and infusoria in the rumen of ruminants, as a result of which these microorganisms use fiber intensively, transforming it for more accessible for the animal organism [12].

Conclusions. Legume-and-cereal mixtures in terms of nutrition meet the biological requirements of animal feeding much more fully. In such sowings due to the selection of different species and varieties of legume and cereal components, which complement each other not only in protein content but also in the number of amino acids, carbohydrates, vitamins and other biologically active substances under joint growing in the agrophytocenosis compared to single-crop sowing of cereals.

Providing livestock with high-quality fodders due to legume-and-cereal mixtures of annual crops is of great importance and makes it possible to expand the range of fodders in the diets of ruminants in the stall period.

\section{Література}

1. Л Лихочвор В. В., Петриченко В. Ф., Іващук П. В. Зерновиробництво. Львів: НВФ «Українські технології», 2008. 624 с.

2. Величко О. В. Ефективність виробництва та використання кормів. Формування ринкових відносин в Украӥні. 2012. №8 (135). С. 111-115.

3. Вика. Ботанічна характеристика вики ярої та озимої. Режим доступу станом на 01.09.2020: http://www.agrobox.com.ua.

4. Бондаренко М. П., Собко М. Г., Собко Н. А. Особливості 
вирощування сумішок однорічних кормових культур. Сад: Інститут сільського господарства Північного Сходу. 2011. 16 с.

5. Бабич А. О. Проблема білка і вирощування зернобобових на корм. Київ: Урожай, 1993. 192 с.

6. Петриченко В. Ф., Гетман Н. Я., Квітко Г. П. Агробіологічні підходи до інтенсифікації польового кормовиробництва в Україні. Корми $i$ кормовиробництво. 2008. № 60 С. 3-13.

7. Richárd Hoffmann, Bernadett Kovács. Compare to different green roughage nutritional value and productivity on southern Transdanubian region. Bulletin UASVM Agriculture. 2011. 68(1). P.168-173.

8. Mr Rade Matic. Improved vetch varieties for fodder production. A report for the Rural Industries Research and Development Corporation. RIRDC Publication. July, 2007. No 07/123.

9. Бахмат М.І., Дутка Г.П., Рак Л.І., Якубишин Б.К., Скаржинський В.Ф., Федоренко В.М. Вплив норм i термінів внесення мінеральних добрив напродуктивність та якість пасовищної трави складного бобово-злакового фітоценозу на пасовищах для ВРХ і коней. Корми і кормовиробництвво. 2006. Вип. 56. С. 84-91.

10. Смирнов П. М., Муравин Э. А. Роль отдельных элементов в жизни растений. Вынос питательных веществ с урожаем сельскохозяйственных культур. Агроном. 2008. №4. С. 18-23.

11. Корнійчук О. В., Гетман Н. Я., Векленко Ю. А., Курнаєв О.М, та ін. Технології вирощування сумішей однорічних культур для заготівлі високобілкових кормів: науково-практичні рекомендації. Вінниця, 2015. 18 с.

12. Aasim M., Sahin-Demirbag N., Mahmood Khawar Kh., Kendir H., Ozcan S. Direct axillary shoot regeneration from the mature seed explant of the hairy vetch (Vicia villosa Roth). Arch. Biol. Sci., Belgrade.2011. 63 (3). P. 757-762.

\section{References}

1. Lyxochvor, V., Petrychenko, V., Ivashhuk, P. (2008). Grain production. Lviv: NVF "Ukrayinski texnologiyi", 624 p. [in Ukranian].

2. Velychko, O. V. (2012). Efficiency of feed production and use. Formation of market relations in Ukraine, no. 8 (135), pp. 111-115 [in Ukranian].

3. Vicia. Botanical characteristics of spring and winter vetch. URL: http://www.agrobox.com.ua.

4. Bondarenko, M. P., Sobko, M. G., Sobko, N. A. (2011). Features of growing mixtures of annual forage crops. Garden: Institute of agriculture of Nothern East, 16 p. [in Ukranian].

5. Babych, A. O. (1993). The problem of protein and growing legumes for feed. Kyyiv: Urozhaj, 192 p. [in Ukranian].

6. Petrychenko, V. F., Getman, N. Ya., Kvitko, G. P. (2008). Agrobiological approaches to the intensification of field fodder production in Ukraine. Kormy i kormovyrobnycztvo, no. 60, pp. 3-13 [in Ukranian].

7. Noffmann R., Kovács, B. (2011). Sompare to different green roughage 
nutritional value and productivity on southern Transdanubian region. Bulletin UASVM Agriculture, no. 68(1), pp. 168-173.

8. Mr Rade Matic. (2007) Improved vetch varieties for fodder production. A report for the Rural Industries Research and Development Corporation. RIRDC Publication. July, 2007. No 07/123.

9. Baxmat, M. I., Dutka, G. P., Rak, L. I., Yakubyshyn, B. K., Skarzhynskyj, V. F., Fedorenko, V. M. (2006). Influence of norms and terms of mineral fertilizers application on productivity and quality of pasture grass of complex legume-cereal phytocenosis on pastures for cattle and horses. Kormy $i$ kormovyrobnycztvo, Iss. 56, pp. 84-91 [in Ukranian].

10. Smyrnov, P. M., Muravyn, E. A. (2008). The role of individual elements in plant life. Carrying out nutrients with crop yields. Rol otdelnbx эlementov v zhyzny rastenyj. Agronomist, no. 4, pp. 18-23 [in Ukranian].

11. Kornijchuk, O. V., Getman, N. Ya., Veklenko, Yu. A., Kurnayev, O.M. et al (2015). Technology of growing the sum of the same crops for the procurement of high-quality food: scientific and practical recommendations. Vinnycya, 18 p. [in Ukranian].

12. Aasim M., Sahin-Demirbag N.,. Mahmood Khawar Kh, Kendir H., Ozcan S. (2011). Direct axillary shoot regeneration from the mature seed explant of the hairy vetch (Vicia villosa Roth). Arch. Biol. Sci., Belgrade.

\section{Аннотация}

Демидась Г. И., Полторецкий С. П., Бурко Л. М., Вейлер С. С. Бинарные посевы, как основа интенсификации отрасли кормопроизводства

В саттье сделано аналитический обзор литературы украинского и мирового передового опыта по вопросам выращивания вики посевной в бинарных посевах. Проанализированы научные публикачии отечественных и зарубежных ученых по вопросам значение бинарных посевов в кормопроизводстве, подбор полевых культур для совместного выращивания. Проведено обобщение и систематизаџия изученного материала. Целью исследований было провести аналитический обзор литературы украинского и мирового передового опыта по выращиванию вики посевной в бинарных посевах.

Во время выполнения исследований применяли общенаучные методы, в частности, следующие: гипотеза, наблюдение, анализ, синтез, индукиия и дедукиия, абстрагирование и обобщение. Материалом были собственные наблюдения $и$ литературные источники по выбранному направлению исследований. Для достижения поставленной цели были проанализировань научные публикачии отечественных и зарубежных ученых по вопросам значение бинарных посевов в кормопроизводстве, подборе полевых культур для совместного выращивания. Проведено обобщение и систематизащия изученного научного материала. 
Выводы. Установлено, что вика посевная преимущественно культивируется в смеси с яровыми хлебными злаками. Эту культуру можно выращивать как при весеннем, так и при летнем посеве в послеукосных $u$ пожнивных посевах с овсом, ячменем, суданской травой и другими яровыми злаковими культурами; за засушливых условий с континентальным климатом - на сено и семена. Однако, урожай семян в таких регионах очень низкий и значительно варьирует в зависимости от количества и распределения весенних дождей. Обеспечение животноводства высококачественными кормами за счет бобово-злаковых смесей однолетних культур дает возможность расширить ассортимент кормов в рационах жвачных животных в стойловый период.

Ключевые слова: вика посевная, бинарные посевы, урожайность, зеленая масса, питательность, тритикале, кормовые единицы, совместимые посевь.

\section{Annotation}

\section{Demydas H. I., Poltoretskyi S. P., Burko L. M., Veiler S. S. Binary sowings as a basis for the intensification of fodder production industry}

In the article analytical literature review of Ukrainian and world best practices on common vetch growing in binary sowings was conducted. Scientific publications of domestic and foreign scientists on the significance of binary crops in fodder production, selection of crops for joint cultivation were analyzed. The generalization and systematization of the studied material was carried out. Purpose of the research was to conduct an analytical literature review of Ukrainian and world best practices on common vetch growing in binary crops.

General scientific methods, in particular, the following: hypothesis, observation, analysis, synthesis, induction and deduction, abstraction and generalization were used during the research. Own observations and literature sources from the chosen field of research were the uased in the material. Scientific publications of domestic and foreign scientists on the significancy of binary crops in fodder production, selection of crops for joint growing were analyzed to achieve this purpose. Generalization and systematization of the studied in tha research material was carried out.

Conclusions. It was found that common vetch is mainly cultivated in mixtures with spring cereals. This crop can be grown for both spring and summer sowing in topping and post-harvest sowings with oats, barley, Sudan grass and other spring cereal crops; for hay and seeds - in arid conditions with a continental climate. However, seed yields in such regions are very low and vary considerably depending on the amount and distribution of spring rains. Providing of livestock production with high-quality fodders due to legume-and-cereal mixtures of annual crops makes it possible to expand the range of fodders in the diets of ruminants in the stall period.

Keywords: Vicia sativa, binary sowings, yield, green mass, nutritional value, triticale, fodder units, joint sowings. 